\title{
Epigraphy and Blurring Senses of the Past in Early Modern Travelling Men of Letters: The Case of Arnoldus Buchelius
}

\author{
Harald Hendrix
}

Whereas early modern intellectuals all over Europe were deeply informed by the orientation on classical culture their breeding had presented as preferred cultural and civic model, their understanding and appreciation of heritage was far more flexible. Though maintaining and indeed cultivating attitudes and methodologies acquired in a scholarly formation focused on the antiquity, from the early sixteenth century onwards men of letters started to develop an interest in various kinds of heritage, old and recent, nearby and far away, sometimes aware of the distinctiveness of the various categories taken into consideration, but often not. This chapter intends to assess how particularly in the community of antiquarians programmatically oriented towards the heritage of the antiquity, medieval and even more recent heritage gradually came to attract an attention that in some instances even surpassed the focus on the classics. While doing so, it will illustrate that in this period a clear-cut distinction between an orientation towards ancient and more recent heritage was not as sharp as conventionally assumed, which clearly holds some consequences as to the main issue addressed in this book. If the boundaries between the various categories of "past" that may be seen as appropriate were in fact rather blurred, one may ask if it is still possible to conjecture that some elements in the past were considered to be appropriate and others not, or - conversely should we conclude that early modern culture appreciated all heritage as being appropriate, without distinction?

To tackle this question, in this essay I focus not only on which past was being targeted by the antiquarians here presented, but also on the motivations that guided them to do so and the tools they used in their endeavours. One of the central hypotheses that inform this survey is indeed the idea that early modern intellectuals might have been flexible as to content, but were not with regard to method. On the contrary: the stability and continuity of their scholarly attitudes and instruments permitted and even invited the exploration of all kinds of evidence beyond the ancient ones learned about during education, and therefore made an interest in various and alternative pasts feasible and

(C) HARALD HENDRIX, 2019 | DOI:10.1163/9789004378216_016

This is an open access chapter distributed under the terms of the prevailing CC-BY-NC-ND License at the time of publication. 
acceptable. Additionally, I hope to show that the manner of looking at and appreciating heritage introduced by these antiquarians did not remain a purely scholarly matter, but found its way far beyond the erudite circles of the scholars themselves and developed into a general template for all those interested in dealing with a past to be considered appropriate.

In order to illustrate this line of thought I focus on a specific genre of texts that function as repositories, even proto-archives, of some of the material traces that document such heritage: the collections of epigraphical materials we may find all over Europe in the sixteenth and seventeenth centuries, in books and in manuscripts. This unusually rich yet still largely unexplored genre develops at the intersection of quite different domains in early modern culture: it is both oriented towards ancient and contemporary culture, it is rooted on the one hand in a profoundly humanistic, scholarly and antiquarian culture, but on the other hand also in the processes of local identity construction that produce large quantities of chorographical city descriptions. ${ }^{1}$ And it is closely linked to the rise of early modern travel culture, not only in its educational orientation but also in its commercial developments. Precisely because of its highly dynamic nature, it is in this rapidly developing travel culture that we may find the most captivating samples of the blurring visions on heritage produced within rather strict methodological frameworks that interest us here.

\section{Arnoldus Buchelius}

A fine specimen to illustrate this meeting of scholarly habits, travel dispositions and flexible interests in various categories of heritage - all appreciated, but for different reasons - is the case of the Utrecht humanist Arnoldus Buchelius $\left(1565^{-1641)}\right)^{2}$ Born in 1565 as an illegitimate son to a wealthy

1 Guthke K.S., Epitaph Culture in the West. Variations on a Theme in Cultural History (Lewiston: 2003), part. 37-55, as well as the pioneering investigations in Sparrow J., Visible Words. A Study of Inscriptions in and as Books and Works of Art (Cambridge: 1969) 25-32, and Weiss R., "The Rise of Classical Epigraphy" in his The Renaissance Discovery of Classical Antiquity (Oxford: 1969) 145-166. See also Petrucci A., Writing the Dead. Death and Writing Strategies in the Western Tradition (Stanford: 1998) 84-85, and Federici F., "L'interesse per le lastre tombali medievali a Roma tra ricerche epigrafiche e documentazione figurativa (secoli XVI-XIX)", Opera - Nomina - Historiae. Giornale di cultura artistica 4 (2011) 161-210.

2 On Buchelius cf. Pollmann J., Religious Choice in the Dutch Republic. The Reformation of Arnoldus Buchelius (1565-1641) (Manchester: 1999), and Langereis S., Geschiedenis als ambacht. Oudheidkunde in de Gouden Eeuw: Arnoldus Buchelius en Petrus Scriverius (Hilversum: 2001); see also Langeraad L.A. van, "Het leven van Arend van Buchell", in Diarium van Arend van Buchel, ed. G. Brom and L.A. van Langeraad (Amsterdam: 1907); Buchell Arnold van, 
patrician, Buchelius' personal interest in his family's history produced a true passion for genealogical research on patrician families in general. ${ }^{3}$ As a youngster he received some training and experience in land surveying, since that was the profession of his stepfather, and when in his early twenties he went as a student to Paris, he came into contact with a number of humanist scholars, notably Lodovico Carrio and Philips van Winge, ${ }^{4}$ who at that very moment were engaged in a major project of chorography: the updating and elaboration of Giles Corrozet's seminal city guide of Paris, the Antiquitez, Chroniques et Singularitez de Paris. In its 1586 edition, this elaborate city guide incorporated all kinds of information on recent monuments, like the royal tombs in Saint Denis. This additional information was in part gathered by Buchelius, who acted as an assistant on this project, as is apparent from the drawings of some of these tombs included in the account of his Parisian years recorded after returning to his hometown in 1588, the well-known Diarium or Commentarius rerum quotidianarum. ${ }^{5}$

Yet what in Paris had started as a mere passion for collecting "nugae / trifles" - as Buchelius in a 1586 letter to a friend ironically defined his start as an antiquarian eager to record in writing and drawing epitaphs and remains of antique buildings $-{ }^{6}$ quickly grew into a much more serious endeavour. This is apparent from the parts in his Diarium intended to serve as a chorography of his hometown Utrecht and written as of 1588 , since these pages reflect the radical changes to the cityscape produced by the introduction of a Calvinist city government headed by the Earl of Leicester, and lament in particular the lack of respect for those monuments that document the medieval glory of Utrecht, based on its churches and other ecclesiastical buildings.

Notae quotidianae, ed.J.W.C. van Campen (Utrecht: 1940); idem, Res Pictoriae. Aantekeningen over kunstenaars en kunstwerken, 1583-1639, ed. G.J. Hoogewerff and J.Q. van Regteren Altena (The Hague: 1928).

3 On Buchelius's religious orientation and his shift from catholicism to calvinism, see Pollmann, Religious Choice.

4 See Hoogewerff G.J., "Philips van Winghe", Mededelingen van het Nederlandsch Historisch Instituut te Rome 7 (1927) 59-82; Schuddeboom C., Philips van Winghe (1560-1592) en het ontstaan van de christelijke archeologie, Ph.D. dissertation (Leiden University: 1996).

5 Buchelius Arnoldus, Commentarius rerum quotidianarum, Utrecht University Library, ms. 798; published in Diarium van Arend van Buchell, and online available at http://www.utrecht sekronieken.nl/kronieken/diarium/ (retrieved 22nd October 2017); the images of the Saint Denis tombs at fols. $189 \mathrm{v}-190$.

6 Letter dd 12 October 1586 to Adam Verdenius, in Buchelius Arnoldus, Epistolae ad diversos, Utrecht University Library, ms 984, fols. 2v-3r; cf. Pollmann, Religious Choice 47. 
Monumenta nil curant veterum aut maiorem memorias, caelo iam sua nomina scripta dicentes, adeo quidam eorum vel ipsis Gottis barbariores.

They neglect the monuments of the ancients, and do not attend to the memorial masses of our ancestors, saying that their names have already been written in heaven, so that some of them seem more barbaric than the Goths themselves. ${ }^{7}$

To counter this iconoclast attack on the city's medieval material heritage, Buchelius includes in his chorography detailed designs of some of the monuments only very recently destroyed, like the church of Saint Salvator demolished in 1587-1588. This drive to document in writings and drawings recent heritage in order to preserve it from possible destruction motivated Buchelius at a later stage in his life to embark on a project scaled even larger. When after 1611 he decided to discontinue his career in public office and dedicate his life entirely to antiquarian research, Buchelius started a comprehensive documentation campaign of the epigraphical and related genealogical materials to be found in the Low Countries, a monumental project which would occupy him for three decades, from 1611 till his death in 1641.

This would produce a series of beautifully illustrated manuscripts containing comprehensive collections of epitaphs and related materials, particularly family coats of arms, starting with the material to be found in his hometown Utrecht collected in the Monumenta passim in templis ac monasteriis Trajectinae urbis atque agri inventa. ${ }^{8}$ As he again specifies in his Introduction, Buchelius felt the need to start this project to document and preserve in written form these monuments, because he had witnessed how war had destroyed so many others: 9

hoc in libro tantum ea collecturus sum, quae adhuc in templis ac locis publicis, partim cum temporis iniuria luctantia, partim hoc nostro

7 Buchelius, Commentarius, fol. 44v; English translation taken from Pollmann, Religious Choice 86.

8 Buchelius Arnoldus, Monumenta passim in templis ac monasteriis Trajectinae urbis atque agri inventa, Het Utrechts Archief, ms. XxviI L 1; available online, together with a detailed description by Joke Mammen, at http://www.utrechtsekronieken.nl (retrieved 22nd October 2017).

9 Similar motivations inform John Stow's 1598 A Survay of London; cf. Newstok S.L., Quoting Death in Early Modern England. The Poetics of Epitaphs Beyond the Tomb (Houndmills: 2009) 100-104. Also some of the earlier humanists interested in collecting epigraphical evidence, notably Fra Giocondo, profess such motivations, on which cf. Weiss, "The Rise of Classical Epigraphy" 150-151. 
demum aevo posita supersunt monumenta [...]; neque ea verbis modo sed et forma sua, lineamentis ac coloribus quantum licebit, exprimere conabor. Aegris enim oculis tot nuper sepulcrorum aliorumque tam publicorum quam privatorum operum monumenta bellorum civilium iniquitate deperdita et irrecuperabili calamitate extincta per totum Belgium inspexi [...].

In this book I intend to collect only those monuments that are still present in churches and public buildings, partly suffering from the threatening effect of time, partly erected only in our own days [...]. I will represent these monuments not only in words but also with coloured drawings, as much as I can. Because I have witnessed recently and with regret how in the entire Low Countries the remains of many sepulchral monuments and other public and private heritage have been lost because of the destructions caused by civil war and thus have disappeared without any chance of repair. ${ }^{10}$

So what he did was visit a large number of churches and monasteries and record in detail, in text and colour drawings, what he saw. Clearly this project to produce a repository of historical memories was motivated by feelings of local identity, since his initial collection, which we can date to around 1610, contained only Utrecht-related materials described in 172 folio pages. But later on he expanded this to other regions, producing a second repository mounting up to 464 pages, the Inscriptiones monumentaque in templis et monasteriis Belgicis inventa, ${ }^{11}$ that presents material from all over the Low Countries [Fig. 14.1], both in the North and in the South, and a third one, the Monumenta quaedam sepulcralia et publica that present 34 folio pages dedicated to monuments in the Northern provinces of Friesland and Groningen, but with some elements from abroad, like the epitaphs Buchelius collected on his foreign trips to Liège and Orléans. ${ }^{12}$

\footnotetext{
10 Buchelius, Monumenta 4r. (translation mine), cf. Langereis, Geschiedenis als ambacht 87, n. 84 .

11 Buchelius Arnoldus, Inscriptiones monumentaque in templis et monasteriis Belgicis inventa, Universiteitsbibliotheek Utrecht, ms. 1648.

12 Buchel Aernout van, Monumenta quaedam sepulchralia, et publica in templis, aliisque locis inventa et descripta, quae in libris observationum ac hactenus descriptorum monumentorum meis non habentur, Tresoar, Leeuwarden, ms. EvC 1323 A.
} 


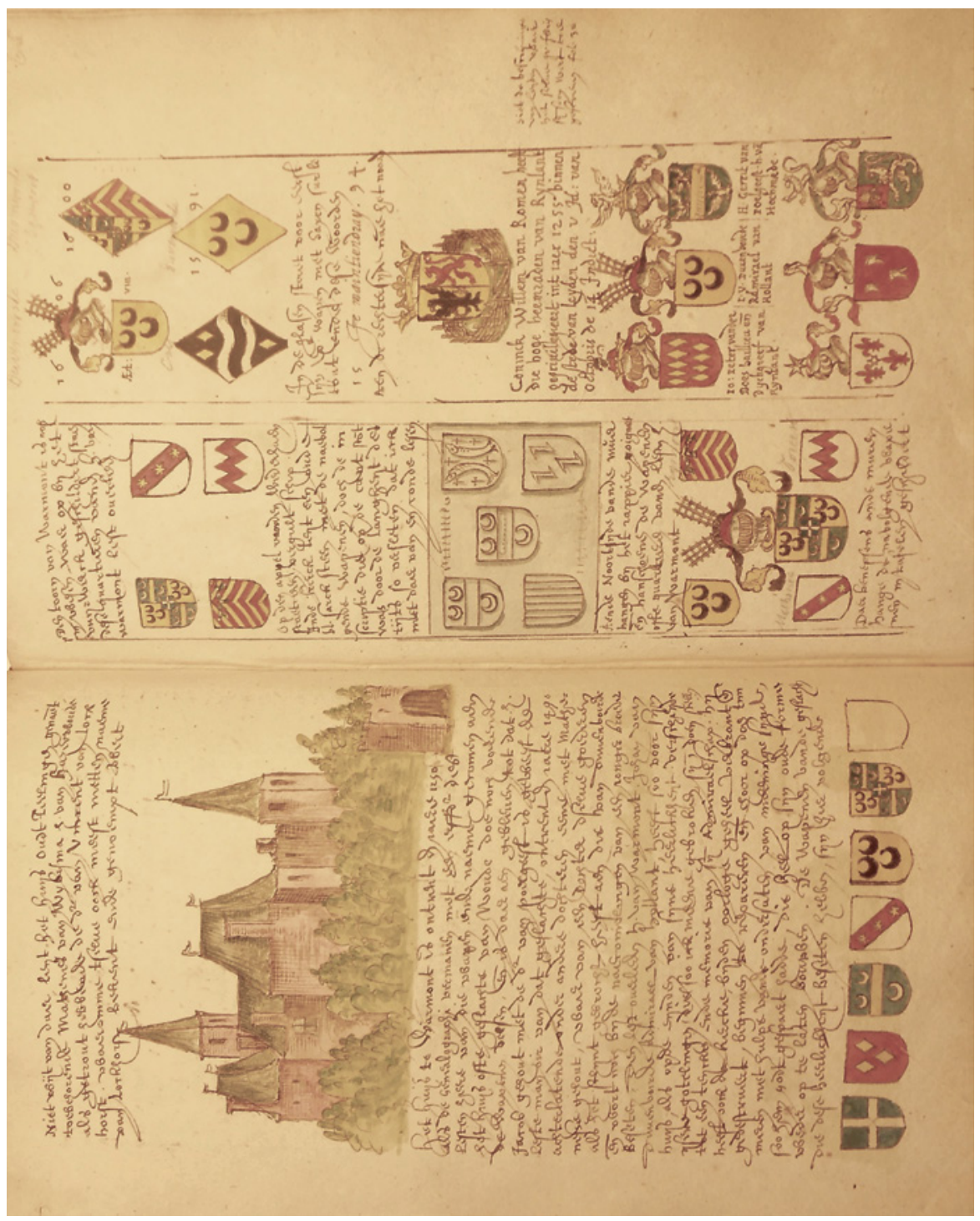

בే 
Buchelius's passion for epigraphy thus had a complex background: it was motivated by feelings of local pride and by the increasing awareness that the heritage he documented was under threat. It was informed by a rudimentary training in survey techniques, and by the experience gathered in the project to update the Parisian chorography of Corrozet with documentation on recently erected monuments. In addition to this, however, and perhaps primarily, it was a habit experimented with on a large scale during his educational travels to Italy, in 1587-1588, and in the subsequent process of elaborating his notes into a travelogue. ${ }^{13}$ Following in the footsteps of earlier antiquarians from the North - like his fellow countryman Stephanus Pighius (1520-1604) - eager to personally observe and record the ancient heritage they had learned about during their education, on his Italian journey Buchelius took on-the-spot notes of the most remarkable monuments he came across, dwelling with particular attention on the epigraphical evidence they presented. ${ }^{14}$ After his return home he started to elaborate these with the help of additional reference works into a travelogue, the Iter italicum, to be included in his Diarium, ${ }^{15}$ just as Pighius had reworked his notes into a seminal travelogue included in his Hercules Prodicius, a book

13 Buchelius travelled to and in Italy from November 1587 through April 1588. On this Italian tour and its travelogue Jan de Jong is conducting an ongoing research project, which has resulted in a series of articles, partly co-authored with Sjef Kemper: Jong J. de, Kemper S., "Historiam hanc diu quaesitam invenire non potui'. Aernout van Buchel op het Capitool", in Egmond M. Van - Jaski B. - Mulders H. (eds.), Bijzonder onderzoek. Een ontdekkingsreis door de bijzondere collecties van de Universiteitsbibliotheek Utrecht (Utrecht: 2009) 48-55; Jong J. de, "Iacet in colle....' Siena in een beschrijving van Aernout van Buchel (1588)", Frons. Blad voor Leidse classici (2010) 41-52; Jong J. de, Kemper S., "Where the Gate drips near the Vipsania Columns'. Aernout van Buchel Gathering Information on the Culture and History of Rome", Fragmenta. Journal of the Royal Netherlands Institute in Rome 5 (2011) 63-100; Jong J. de, Kemper J., "La visione di Roma dell'olandese Arnoldus Buchelius (dicembre 1588)", Studi umanistici piceni 31 (2011) 187-198; Jong J. de, Kemper S., "Aernout van Buchel in Napels", Incontri. Rivista europea di studi italiani, 27 (2011) 3-20; Jong J. de, "Responding to Tomb Monuments. Meditations and Irritations of Aernout van Buchel in Rome (1587-1588)", in Brusati C., Enenkel K., Melion W. (eds.), The Authority of the Word. Reflecting on Image and Text in Northern Europe, 1400-1700 (Leiden-Boston: 2012) 533-558; Jong J. de, "Aernout van Buchel's Description of Italy, 1587-1588", Print Quarterly 33 (2016) 123-134.

14 The two notebooks are in the Utrecht University Library: mss. 760 (notes on the Italian trip and Rome) and 1640 (notes on Naples).

15 Buchelius, Commentarius, I-91, published in Buchelius A., Iter italicum, ed. Rodolfo Lanciani (Roma: 1901). Cf. also Buchelius Arnoldus, Rerum memorabilium diversarum observationum itineris mei Germanici et Italici commentariolus, ms. Het Utrechts Archief (Hs. 761), published in Diarium van Arend van Buchel, and online available at http://www .utrechtsekronieken.nl/kronieken/diarium/ (retrieved 22nd October 2017). 
that immediately after its 1587 publication for Buchelius served as an authorative guide on his Italian tour and during the process of elaborating his notes. ${ }^{16}$

Since Buchelius' work on the Iter italicum coincided with his decision to start also in his native Utrecht campaigns to document such evidence on local monuments, his travelogue enables us to better understand his working habits as well as his intellectual attitudes and dispositions at a crucial turning point in his scholarly career. Essential in this approach is the combination and indeed connection of hands-on observations gathered while travelling with erudite knowledge collected from reference works and authorative sources. This working habit, which he might as well have adopted from his guide Pighius who equally had applied such methods in his recent travelogue, brings him to transfer antiquarian methods traditionally oriented exclusively towards evidence of ancient remains to a much vaster range of monumental artefacts encountered while travelling.

As a result Buchelius focuses in his report on a variety of heritage that is much broader than a conventional antiquarian approach would appreciate, ranging from the ancient and early Christian to late medieval and even contemporary culture. In Ravenna he reports on ancient, Byzantine and modern artefacts like Dante's tomb erected in 1483-, and in Florence he admires Michelangelo's tomb in Santa Croce completed only a decade before his visit. ${ }^{17}$ In the section on Rome, he includes drawings not only of the Basilica of Maxentius and the Molis Hadriani [Fig. 14.2], but also of the contemporary building campaign transforming Capitol Hill into an ensemble designed by Michelangelo. ${ }^{18}$ And this large range of heritage items is presented without much distinction,

16 Pighius Stephanus, Hercules Prodicius seu Principis iuventutis vita et peregrinatio (Antwerp, Christopher Plantin: 1587). The antiquarian Pighius had extensively travelled Italy during the years of his service to cardinal Cervini (1548-1556) and in 1573-1575 as tutor of the hereditary duke of Cleves. Most part of his manuscript notes are now in the Codex Pighianus (Berlin, Staatsbibliothek, ms. lat. fol. 61). On his 1573-1575 tour he composed an elaborate travelogue integrating notes taken during his previous visits, the Hercules Prodicius, published only in 1587 with Plantin in Antwerp. The recent publication of this seminal antiquarian guide to Italy produced by a humanist from the Utrecht circle might have stimulated Buchelius to embark on an Italian journey himself. On Pighius cf. Jongkees J.H., "Stephanus Winandus Pighius Campensis", Mededelingen van het Nederlandsch Historisch Instituut te Rome 8 (1954) 120-185, and particularly on his Italian tour: Laureys M., "Theory and practice of the journey to Italy in the 16th century: Stephanus Pighius' Hercules Prodicius", in Sacré D., Tournoy G. (eds.), Myricae. Essays on Neo-Latin literature in memory of Jozef IJsewijn (Leuven: 2000) 269-301.

17 Buchelius, Iter italicum 27-31 (Ravenna), 137 (tomb Michelangelo).

18 On this particular section in Buchelius' travelogue, with special reference to the drawings and their provenance, cf. Jong - Kemper, "Historiam hanc diu quaesitam invenire non potui"”. 
suggesting therefore that even an erudite man like Buchelius had only a limited awareness of such distinctions and lacked the motivation to draft hierarchies in what was to be considered valuable or appropriate past.

What however connects many of these diverse kinds of heritage in the mindset we may deduct from Buchelius' travelogue is the written evidence many of them present in the format of epitaphs or other epigraphical specimens. His interest in the recent tombs of the likes of Dante and Michelangelo is triggered by a curiosity focused on the epitaphs the monuments present and by the desire to record such evidence. This indicates that Buchelius's observation of the reality he witnesses while travelling is dominated and indeed limited by a preference for written testimonies illustrating the heritage observed, a phenomenon characteristic of most antiquarians. What however distinguishes Buchelius' version of what one might coin as "epigraphical gaze" is that it developed from an orientation on ancient heritage, yet mediates and indeed invites a wider curiosity for all such material traces that present written evidence, regardless of their chronological or cultural provenance. This is a disposition that informs also Buchelius' slightly later endeavour to record and preserve the modern epigraphical and genealogical materials he finds in Utrecht and in the Low Countries at large: while the instrument derives from a typically antiquarian approach developed in an explorative dialogue with the antiquity, the content is modern and local heritage.

Yet Buchelius was not a man to develop himself such an innovative combination of ancient and modern. For this, he could rely on his usual guides, primarily Pighius, but even more so on the reference works he used during and after his Italian tour, books that had partly informed Pighius' Hercules Prodicius as well, like for example the well-known chorography of Ravenna, Desiderio Spreti's De amplitudine, de vastatione et de instauratione urbis Ravenna, which was republished only a few years before Buchelius' Italian tour, in 1574 and again in 1588, and is duly cited as being consulted during the writing of his travelogue. ${ }^{19}$ As of its first edition published in 1489, Spreti's chorography had included an appendix on the epigraphical materials to be found in Ravenna's monumental religious buildings, both ancient and modern. ${ }^{20}$ Likewise Buchelius made use of

\footnotetext{
19 Buchelius, Iter italicum 28.

20 Spreti Desiderio, De amplitudine, de vastatione et de instauratione urbis Ravenna (Venice, Guerra: 1588) 53-64, "Epigrammata".
} 


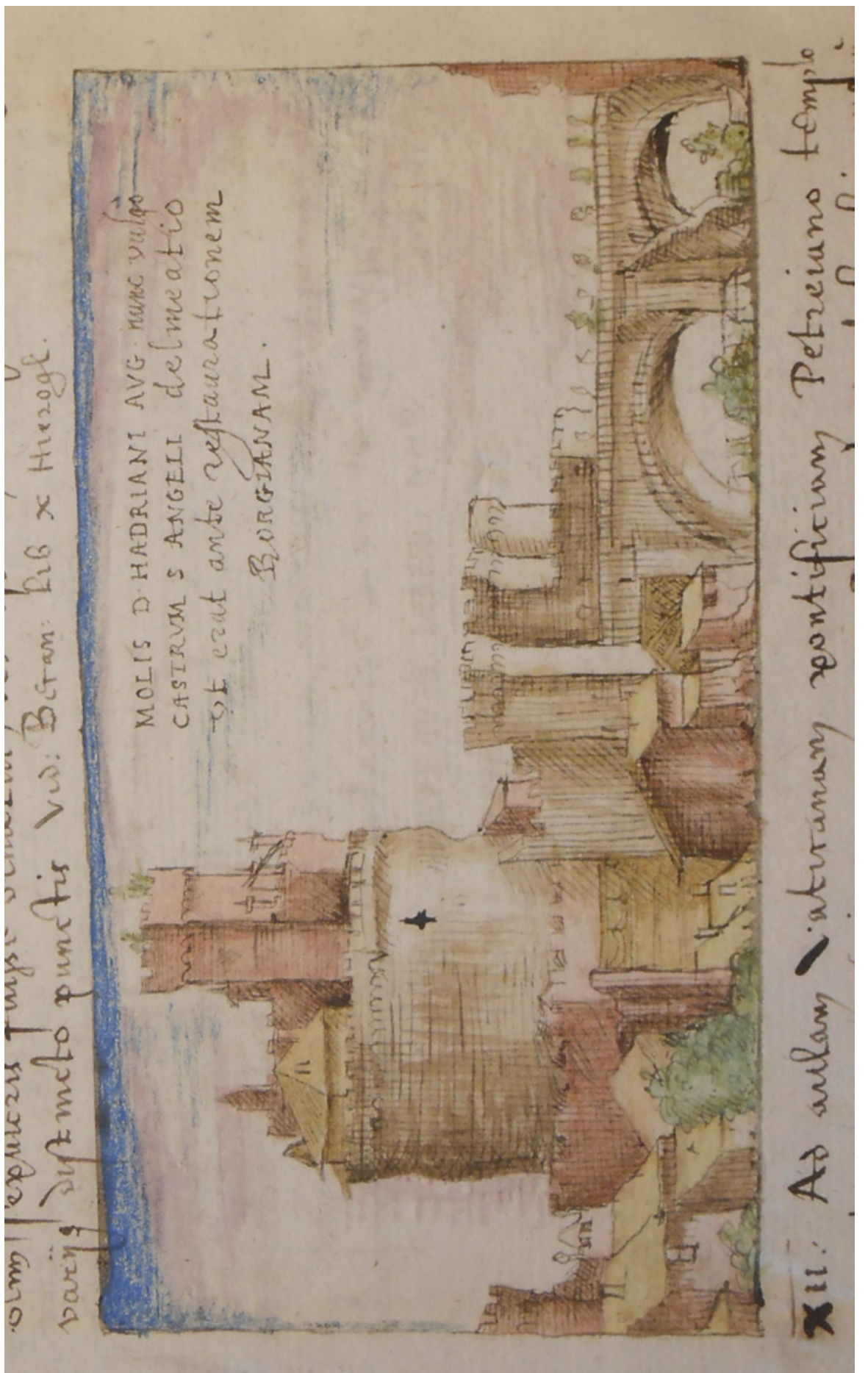

|⿱宀 
Bernardino Scardeone's monumental chorography of Padua published in 1560, a work that includes a supplement De sepulchris insignibus [Fig. 14.3] which even gives reproductions of the exact material forms of the mostly modern epigraphs it describes, exactly as Buchelius sometimes does in his travelogue. ${ }^{21}$

These examples illustrate that the project of collecting, documenting and preserving epigraphical materials is closely linked to the art of describing cities or similar geographical entities, and therefore informed by ambitions we might now describe in terms of identity constructions. Both Spreti's and Scardeone's projects in fact were rooted in a desire to boost their hometown's civic identity by stressing its ancient roots. The same goes for the first epigraphical collections that were published independently, and thus not as part of a chorography. This tradition starts outside of Italy, with the 1505 Romanae vetustatis fragmenta in Augusta Vindelicorum et eius diocesi, collected and published by Konrad Peutinger, thus stressing Augsburg's direct connection to Roman Antiquity, as the graphically exact reproductions of the epigraphs underline. ${ }^{22}$ But it also goes for the famous collection published at the instance of Raimund Fugger, the Inscriptiones sacrosanctae vetustatis, collected by Petrus Apianus and Bartholomeus Amantius in $1534,{ }^{23}$ a repository of ancient epigraphs coming from all over Europe but (mostly) present in the local Augsburg antiquity collections. Being the description of collections, the publication here develops into something of a catalogue, with two-dimensional reproductions of the artefacts.

What emerges in these early collections of epigraphic materials is the clearcut antiquarian orientation on the Roman past as the sole pathway to glory. Yet paradoxically in the Italian context of the early chorographies of men like Spreti and Cardeone this concept of heritage able to support a city's claim to glory incorporates also the epigraphical evidence of other pasts clearly accepted as being appropriate: from the early Christian to the modern age.

21 Scardeone Bernardino, Historiae de urbis Patavii antiquitate, claris civibus Patavinis libri tres, in quindecim classes distincti, eiusdem Appendix De sepulchris insignibus exterorum Patavii iacentium (Basel, Nicolaus Episcopius: 1560) 381-437, "De sepulcris insignibus Patavii iacentium". The reference to Scardeone is in Buchelius, Iter italicum 17.

22 Peutinger Konrad, Romanae vetustatis fragmenta in Augusta Vindelicorum et eius dioecesi (Augsburg, Erhard Ratdolt: 1505); modern edition in Ein Augsburger Humanist und seine römischen Inschriften [...], ed. M. Ferber and G.M. Müller (Lindenberg: 2014) 45-149. See also Ott M., "Konrad Peutinger und die Inschriften des römischen Augsburg: Die 'Romanae vetustatis fragmentae' von 1505 im Kontext”, in Mueller G.M. (ed.), Humanismus und Renaissance in Augsburg (Berlin: 2010) 275-289.

23 Apianus Petrus and Amantius Bartholomeus, Inscriptiones sacrosanctae vetustatis: non illae quidem Romanae, sed totius orbis summo studio [...] conquistae (Ingolstadt, Petrus Apianus: 1534). 

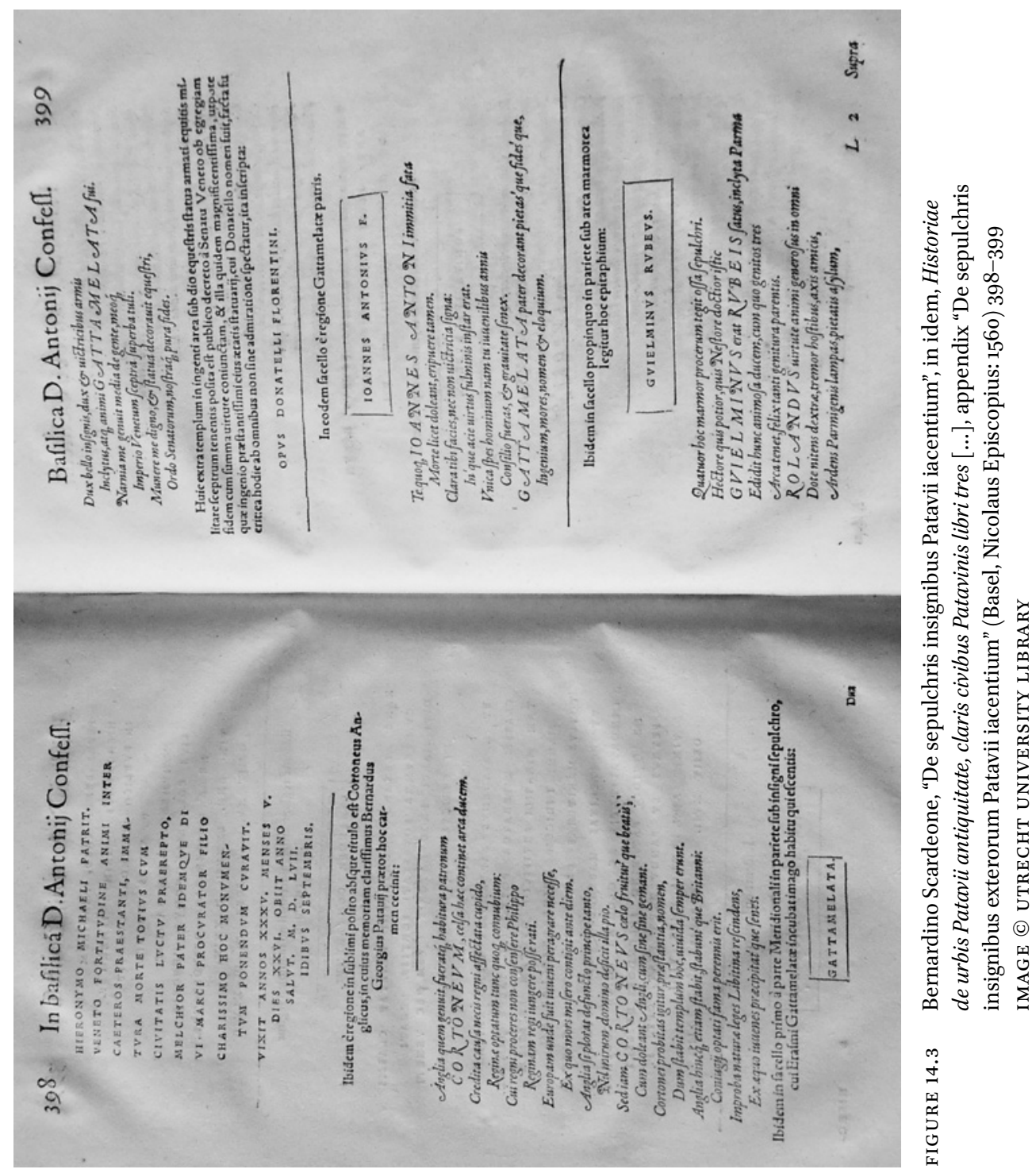

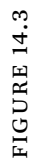


This moreover enables these collections to develop into comprehensive repositories of noteworthy things to be seen by visitors interested in contemplating such materials but without a thorough antiquarian preparation. As a consequence the "epigraphical gaze" here employed also informs the earliest chorographies in vernacular targeting wider audiences of travellers, well beyond the erudite circles of the antiquarians, as we may deduct from a contemporary Italian case, the trend-setting guide of Naples published in 1548, Benedetto di Falco's Descrittione dei luoghi antichi di Napoli e del suo amenissimo distretto, ${ }^{24}$ which contrary to its title reports not only on ancient but also on many recent and even contemporary monuments, and on collections of both ancient and modern art. Characteristically, Di Falco reports at many points in his text the epigraphs present in the locations he describes, translating them systematically into the vernacular, or, when needed, from the Greek original first into Latin and then into Italian, and thus highlighting his ambition to reach an audience not only of erudites. ${ }^{25}$

Being a well prepared traveller to Italy himself, at the time of his journey in 1587-1588 and even more so when ordering and editing his notes some decades later, Buchelius had access to most of this documentation that by then had developed into a kind of a template easily to be imitated. This is what the Utrecht scholar indeed did, not only in the drafting of his travelogue, but also in his parallel project - undertaken between 1610 and 1620 - to compile a comprehensive record of the monuments in his native Utrecht and in the Low Countries at large. In this ambitious and innovative endeavour he was informed by the same passion for epigraphy that by the early seventeenth century had developed into something like a universal and indeed encyclopaedic vehicle for the documentation of heritage, regardless of its orientation. From what once had been a very specific instrument in the antiquarians' project to present Roman Antiquity as the only acceptable benchmark in the definition of new cultural standards, it gradually had incorporated ever more non-ancient materials in its mission to establish modern identities: of cities, regions, families, or professional categories. In the process, it had lost some of its erudite overtunes, transforming into an art accessible and enjoyable also to non-scholarly people with an interest in heritage, particularly travellers eager to document whatever evidence of the past they came across. As a result, the concept of which past

24 di Falco Benedetto, Descrittione dei luoghi antiqui di Napoli (Naples, Giovan Francesco Suganappo: [1548]); modern edition by T.R. Toscano and M. Grippo (Naples: 1992). Cf. Toscano T.R., "Due schede per Benedetto di Falco", Critica letteraria 19 (1991) 725-759.

25 Particularly in his description of the church of San Paolo that had incorporated large parts of the ancient Castor and Pollux temple. 
was relevant to the present had widened up considerably. Alongside antiquity, also medieval and modern elements were taken into consideration, and conventional hierarchies of heritage tended to become obsolete.

Yet this blurring sense of what might be "appropriate past" was framed in and indeed depended on a methodological framework that remained unaltered: the undisputed conviction that the written evidence to be gathered from epigraphy was the preferential tool for all those eager to unravel, document and preserve the past. In this process, the authority originally conveyed to the materials coming from Roman Antiquity was transferred first to the medium of the inscription, and then to the habit of collecting such epigraphical material. This explains the wide appeal of the phenomenon, well beyond the erudite and scholarly circles in which it had originated. Also for those less knowledgeable, like the travellers who from the late sixteenth century onwards started touring Europe in ever growing numbers, taking notes on inscriptions became a habit that gave them an easy access to the heritage they came across, without coercing them to identify which heritage this was and if it had relevance to them. ${ }^{26}$ So whereas the early modern "epigraphical gaze" described in this essay was instrumental in opening up ideas on which past was appropriate and in promoting this liberal vision amongst a large variety of audiences, its appeal and authority rooted in a working method that remained profoundly informed by the antiquarians' cult of Roman heritage.

\section{Bibliography}

Guthke K.S., Epitaph Culture in the West. Variations on a Theme in Cultural History (Lewiston: 2003).

Jong J. de, “Aernout van Buchel's Description of Italy, 1587-1588", Print Quarterly 33 (2016) 123-134.

Langereis S., Geschiedenis als ambacht. Oudheidkunde in de Gouden Eeuw: Arnoldus Buchelius en Petrus Scriverius (Hilversum: 2001).

Laureys M., "Theory and practice of the journey to Italy in the 16th century: Stephanus Pighius' Hercules Prodicius", in Sacré D., Tournoy G. (eds.), Myricae. Essays on NeoLatin literature in memory of Jozef IJsewijn (Leuven: 2000) 269-301.

Pollmann J., Religious Choice in the Dutch Republic. The Reformation of Arnoldus Buchelius (1565-1641) (Manchester: 1999). 